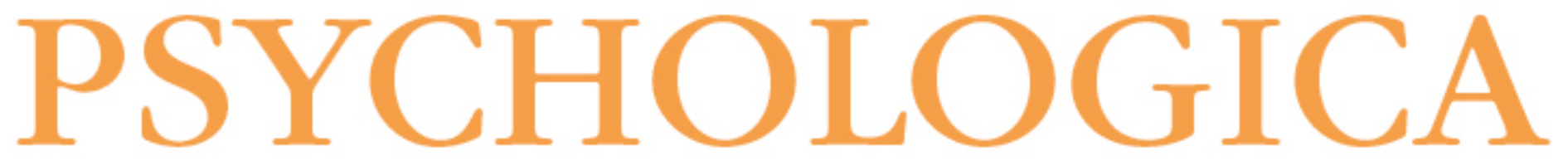

\title{
Early memories of warmth and safeness and eating psychopathology: the mediating role of social safeness and body appreciation
}

\author{
Autor(es): $\quad$ Oliveira, Sara; Ferreira, Cláudia; Mendes, Ana Laura \\ Publicado por: Imprensa da Universidade de Coimbra \\ URL \\ persistente: URI:http://hdl.handle.net/10316.2/41445 \\ DOI: DOI:https://doi.org/10.14195/1647-8606_59_2_3 \\ Accessed : $\quad$ 26-Apr-2023 02:44:25
}

A navegação consulta e descarregamento dos títulos inseridos nas Bibliotecas Digitais UC Digitalis, UC Pombalina e UC Impactum, pressupõem a aceitação plena e sem reservas dos Termos e Condições de Uso destas Bibliotecas Digitais, disponíveis em https://digitalis.uc.pt/pt-pt/termos.

Conforme exposto nos referidos Termos e Condições de Uso, o descarregamento de títulos de acesso restrito requer uma licença válida de autorização devendo o utilizador aceder ao(s) documento(s) a partir de um endereço de IP da instituição detentora da supramencionada licença.

Ao utilizador é apenas permitido o descarregamento para uso pessoal, pelo que o emprego do(s) título(s) descarregado(s) para outro fim, designadamente comercial, carece de autorização do respetivo autor ou editor da obra.

Na medida em que todas as obras da UC Digitalis se encontram protegidas pelo Código do Direito de Autor e Direitos Conexos e demais legislação aplicável, toda a cópia, parcial ou total, deste documento, nos casos em que é legalmente admitida, deverá conter ou fazer-se acompanhar por este aviso.

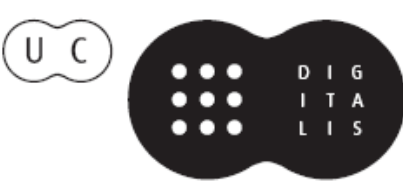


VOLUME

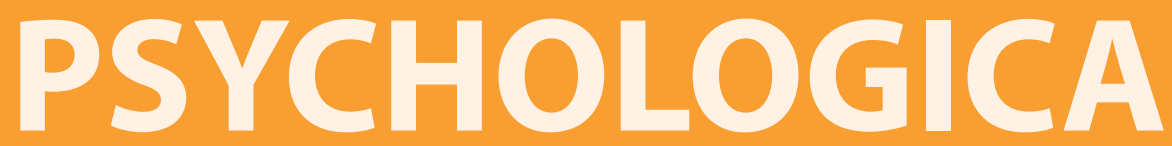

IMPRENSA DA UNIVERSIDADE DE COIMBRA

COIMBRA UNIVERSITY PRESS

FACULDADE DE PSICOLOGIA E DE CIÊNCIAS

DA EDUCAÇÃO DA UNIVERSIDADE DE COIMBRA 


\title{
Early memories of warmth and safeness and eating psychopathology: The mediating role of social safeness and body appreciation
}

\author{
Sara Oliveira ${ }^{1}$, Cláudia Ferreira ${ }^{2}$ and Ana Laura Mendes ${ }^{3}$
}

\begin{abstract}
Research on human development and functioning has highlighted the importance of early emotional and relational experiences. Particularly, an association between the absence of early positive memories and the presence of disordered eating has been evidenced by recent investigations. However, the study of the mechanisms underlying this association remains unclear.

Using a sample of 490 women, the hypothesis that early positive memories are negatively associated with disordered eating via social safeness and a positive relationship with one's body image was tested via path analysis. The tested model explained $51 \%$ of eating psychopathology's variance, and revealed a good adjustment to the empirical data. Additionally, social safeness and body appreciation were revealed as mediators of the impact of early warm and safe memories on disordered eating, when controlling for the effect of BMI. These findings suggest the importance of targeting social safeness and acceptance, especially when defining potentially effective programmes for the prevention of eating disorders.
\end{abstract}

Keywords: early memories; social safeness; body appreciation; disordered eating

1 University of Coimbra, Portugal. Email: sara.oliveira.uc@gmail.com

2 University of Coimbra, Portugal. Email: claudiaferreira@fpce.uc.pt

3 University of Coimbra, Portugal. Email: analauramendes@live.com.pt Artigo recebido a 05-05-2016 e aprovado a 04-06-2016. 


\section{Memórias precoces de calor e segurança e a psicopatologia alimentar: O papel do social safeness e da body appreciation}

\section{Resumo}

A literatura tem sublinhado a importância das experiências afiliativas precoces no desenvolvimento e funcionamento humano. Paralelamente, estudos recentes evidenciaram a relação entre escassez de memórias positivas precoces e o comportamento alimentar perturbado. No entanto, o estudo dos mecanismos subjacentes a esta associação permanece limitado. Este estudo testou um modelo que hipotetiza que memórias positivas precoces estão negativamente associadas à psicopatologia alimentar, através do social safeness e de uma relação positiva e de cuidado com o corpo. A análise path foi conduzida numa amostra de 490 mulheres e confirmou a adequabilidade do modelo, o qual explica $51 \%$ da variância da psicopatologia alimentar. Adicionalmente, o social safeness e a apreciação positiva do corpo (body appreciation) revelaram-se mediadores do impacto das memórias precoces de calor no comportamento alimentar perturbado, controlando o efeito do IMC.

Estes resultados sugerem que o social safeness e a body appreciation poderão ter uma importante contribuição em programas de prevenção de psicopatologia alimentar.

Palavras-chave: memórias precoces; social safeness; apreciação corporal; psicopatologia alimentar

\section{INTRODUCTION}

Literature has shown that early affiliative experiences seem to play an important role in our physical and psychological well-being (Collins, Maccoby, Steinberg, Heatherington, \& Bornstein, 2000; Gilbert \& Perris, 2000; Schore, 1994). In fact, growing evidence has highlighted that early emotional and relational experiences, either positive or negative, are crucial on human development and functioning (e.g., Bowlby, 1969, 1973; Gerhardt, 2004; Panksepp, 2010; Richter, Gilbert, \& McEwan, 2009; Schore, 1994).

Several authors have demonstrated that negative rearing experiences, characterized by rejection, abuse, neglect and shame, are associated with a wide range of interpersonal and emotional difficulties and with higher vulnerability to psychopathology (Gilbert \& Perris, 2000; Irons, Gilbert, Baldwin, Baccus, \& Palmer, 2006), namely eating psychopathology (Ferreira, Matos, Duarte, \& Pinto-Gouveia, 2014; Vartanian et al., 2014). In contrast, early experiences involving positive and 
affiliative signals (e.g., of reassurance, warmth, care or affection) are suggested to be linked to feelings of safeness and acceptance, and therefore promote the development of adaptive emotion regulation processes, and contribute to a greater well-being (e.g., Baldwin \& Dandeneau, 2005).

Empirical studies have proposed that early affiliative experiences or interactions may be registered as powerful autobiographic memories, which can act as conditioned and highly available emotional memories (e.g., Gilbert \& Irons, 2009; Matos \& Pinto-Gouveia, 2010). However, in face of other's behaviours, individuals may display different emotional responses (Gilbert, Cheung, Grandfield, Campey, \& Irons, 2003). In this line, rather than focusing on interactions or others' behaviours, recent research has privileged the study of the recall of early interpersonal interactions, i.e., the way one recalls feelings within early relationships (Gilbert et al., 2003).

In fact, early negative emotional memories (e.g., recollections of a sense of threat, subordination, and feeling ashamed or unvalued as a child; Gilbert et al., 2003) are associated with a higher vulnerability to psychopathology (Xavier, Cunha, \& Pinto-Gouveia, 2015). Also, literature has shown that the inability to recall early warmth and safeness experiences can lead to negative emotional states (e.g., Mendes, Marta-Simões, \& Ferreira, 2016; Richter et al., 2009). In contrast, research suggests that the evocation of memories of early support plays a crucial role in the promotion of feelings of self-warmth, self-compassion and self-soothing, considered relevant psychological adjustment indicators (Gilbert \& Irons, 2009; Gilbert \& Procter, 2006).

Within an evolutionary perspective, positive social interactions seem to stimulate the soothing affiliation system, which promotes feelings of connectedness, soothing and social safeness (e.g., Depue \& Morrone-Strupinsky, 2005; Ferreira et al., 2014; Gilbert, 2009, 2010), and, thus, supports effective coping with adverse experiences (e.g., personal failures and setbacks; Dehart, Peham, \& Tennen, 2006; Richter et al., 2009).

Social safeness is characterized by the presence of feelings of warmth, acceptance and connectedness within interpersonal interactions (Gilbert et al., 2009) and seems to be negatively associated with several psychopathological indicators (such as inferiority, self-criticism and submissive behaviours) and with depressive and anxiety symptoms (e.g., Gilbert et al., 2008; Kelly, Zurroff, Leybman, \& Gilbert, 2012). According to Gilbert $(1989,2005)$, individuals who perceive their social world as safe, warm, and soothing, tend to manage problems and challenging events more effectively and act in a more adaptive manner. On the other hand, when someone does not feel safe in their social contexts and perceives others as unsafe or threatening, he/she needs to stay vigilant and to be ready for engaging in defensive responses (such as shame or submissive behaviours) and to strive for social acceptance.

In the field of body image and eating behaviour, research has highlighted that disordered eating and, specifically, drive for thinness, may emerge as a strategy 
intended to protect oneself from social threats (e.g., being ostracized or rejected due to one's body shape or weight) and to compete for social advantages (such as being accepted, approved and valued by others; Ferreira, Pinto-Gouveia, \& Duarte, 2013; Pinto-Gouveia, Ferreira, \& Duarte, 2014). In this sense, in women who perceive themselves as being in a low social rank (e.g., inferior or unattractive), the engagement in rigid dieting or other weight control behaviours may be conceptualized as a maladaptive strategy aimed to serve the functional purpose of threat regulation and feeling safe in the social group (Goss \& Allan, 2009; Goss \& Gilbert, 2002).

The importance of nurturing a positive and caring relationship with one's own body has been the subject of recent research (Homan \& Tylka, 2015). Body appreciation, defined as a positive, accepting and respecting attitude towards body image, regardless of its appearance (Avalos, Tylka, \& Wood-Barcalow, 2005; Tylka \& Wood-Barcalow, 2015). Moreover, this construct entails more than being satisfied with one's own body image and can be understood as holding a compassionate attitude towards one's own body image. Body appreciation is, therefore, the ability to accept and to be kind towards perceived defects or flaws in appearance, instead of being harshly self-critical, and also to recognize the unappreciated body characteristics as part of the common human experience (e.g., Tylka \& Wood-Barcalow, 2015). Several studies showed that body appreciation is positively associated with outcomes such as optimism, positive affect, self-compassion and life satisfaction, as well as negatively linked with body dissatisfaction, body shame and body image avoidance, and eating psychopathology (e.g., Avalos et al., 2005). However, literature regarding body appreciation is still scarce.

The current study aimed to test an integrative model that explores the impact of the recall of early memories of warmth and safeness on eating psychopathology, and whether social safeness and body appreciation significantly act on this association. It was hypothesized that the recall of positive early affiliative experiences (in relationships with family figures and peers) may be associated with lower eating psychopathology's severity, through higher levels of feelings of acceptance and connectedness in social relationships and body appreciation. In fact, there is evidence that the lack of warmth and safe affiliative memories are linked with the engagement in disordered eating attitudes and behaviours (e.g., Mendes, Marta-Simões, \& Ferreira, 2016). Furthermore, research has pointed out that disordered eating may emerge as a strategy to compete with social acceptance and belonging (Ferreira et al., 2013; Pinto-Gouveia et al., 2014). Additionally, several authors have highlighted body appreciation as a protective strategy that seems to be highly and negatively associated with eating disorders (e.g., Avalos et al., 2005; Tylka \& Barcalow, 2014). Nonetheless, no studies to date have explored a model that explains the paths between these variables and its impact on eating psychopathology. 


\section{MATERIAL AND METHODS}

\section{Participants}

The sample of this study comprised 490 women from the Portuguese general population, with ages ranging from 18 to 55 years old $(M=24.76 ; S D=7.66)$. The majority of participants lived in an urban area $(72.9 \%)$ and $27.1 \%$ in a rural one. Body Mass Index (BMI) ranged between 15.24 and 42.24, with a mean of 22.29 $(S D=3.87)$, which corresponds to normal weight values (BMI ranging from 18.5 to 24.9; WHO, 1995). Moreover, the sample's BMI distribution revealed to be equivalent to the female Portuguese population's BMI distribution (Poínhos et al., 2009).

\section{Procedures}

The present study is part of a wider Portuguese research about the impact of different emotional regulation processes in psychological functioning and mental health. The sample was obtained through online advertisements on social networks, and data collection and other study's procedures respected all ethical and deontological requirements, inherent to scientific research. Individuals who accepted to participate in this research were informed about the voluntary and confidential character of their participation and respective collected data, and gave their written informed consent before completing the test battery.

The initial sample was composed of 514 individuals (494 women and 20 men), with ages ranging from 17 to 57 years old. However, taking into account the purpose of the current study, data cleaning procedures excluded: (a) male participants and (b) participants younger than 18 years old and older than 55 years old.

\section{Measures}

Before answering self-report measures (described below), participants completed a series of questions regarding demographic data (e.g., age, gender, nationality, area of residence and education level) and current weight and height (used to calculate BMI).

Body Mass Index (BMI); BMI was calculated based on participants' self-reported current weight and height using the Quetelet Index $\left(\mathrm{Kg} / \mathrm{m}^{2}\right)$. 
Early Memories of Warmth and Safeness Scale (EMWSS; Richter et al., 2009; Matos, Pinto-Gouveia, \& Duarte, 2014); EMWSS is a self-report measure, composed of 21 items, that aims to assess the recall of early positive emotional experiences with close or family figures. Participants are asked to select, on a 5-point scale (0 = "No, Never" to 4 = "Yes, Most of the time"), the frequency of a set of childhood emotional memories characterized by warmth, safeness, soothing, and care in their relationship within family figures (e.g., "I felt that I was a cherished member of my family"). This measure presented a Cronbach's alpha of .97 , both in the original and Portuguese versions, and of .98 in the current study.

Early Memories of Warmth and Safeness Scale-Peers version (EMWSS_peers; Ferreira, Cunha, Marta-Simões, Duarte, Matos, \& Pinto-Gouveia, 2016); EMWSS peers is a 12-item instrument adapted from the EMWSS (Richter et al., 2009), which evaluates the recall of peer-related early positive emotional experiences. Participants are asked to indicate the frequency of recalled emotional experiences regulated by warmth, safeness and affection in their relationships with friends and colleagues during childhood and adolescence (e.g., "I felt loved by my peers/ friends"). The response options are presented on a 5 -point scale $(0=$ "No, Never" to 4 = "Yes, Most of the time"). This measure presented good psychometric properties, with high levels of internal consistency in the original version $(\alpha=.97)$ and in the current study $(\alpha=.98)$.

Social Safeness and Pleasure Scale (SSPS; Gilbert et al., 2009; Pinto-Gouveia, Matos, \& Dinis, 2008); SSPS is a self-report measure composed of 11 items designed to measure social safeness, i.e., the extent to which individuals feel a sense of acceptance and connectedness in their social relationships (e.g." 'I feel accepted by people"). The response options are rated on a 5 -point scale ( $1=$ "Almost never" to 5 $=$ "Almost all the time"). SSPS has shown good internal consistency in the original study $(\alpha=.92)$; concerning the current study, the Cronbach's alpha was .94.

Body Appreciation Scale (BAS-2; Marta-Simões, Mendes, Oliveira, Trindade, \& Ferreira, 2016; Tylka \& Wood-Barcalow, 2015); BAS-2 is a self-report measure composed of 10 items that aim to assess individuals' acceptance and respect for their bodies, even if not totally pleased with all its aspects (e.g., "I take a positive attitude towards my body"). The response options are rated on a 5-point scale (1 $=$ "Never" to 5 = "Always"). BAS-2 has shown excellent internal consistency in the original study (with Chronbach's alpha values ranging from .93 to .97 in different samples; Tylka et al., 2014) and in Portuguese version $(\alpha=.95)$. Also, in the current study BAS-2 presented high internal consistency $(\alpha=.95)$.

Eating Disorder Examination Questionnaire (EDE-Q; Fairburn \& Beglin, 1994; Machado et al., 2014); EDE-Q is a self-reported measure composed of 36 items, adapted from the Eating Disorder Examination Interview (EDE, 
Fairburn, \& Cooper, 1993), which assesses the frequency and intensity of disordered eating attitudes and behaviours. It comprises four subscales: restraint, weight concern, shape concern and eating concern. The items are rated for the frequency of occurrence (items 1-15, on a scale ranging from $0=$ "None" and 6 = "Every day") or for severity (items 29-36, on a scale ranging from $0=$ "None" and 6 = "Extremely"). EDE-Q's internal consistency revealed to be high both in the original version and in the Portuguese validation study $(\alpha=.94)$, and also in the current study $(\alpha=.95)$.

\section{Data analyses}

Data analyses were performed using the software IBM SPSS Statistics 22.0 (SPSS IBM; Chicago, IL) and path analyses with the software AMOS (Arbuckle, 2008).

Descriptive statistics (means and standard deviations) were performed in order to examine the characteristics of the final sample. Additionally, to explore the associations between age, BMI, early memories of warmth and safeness with close figures (EMWSS) and with peers (EMWSS_peers), social safeness (SSPS), body appreciation (BAS-2) and eating psychopathology (EDE-Q), product-moment Pearson correlations analyses were performed.

The magnitudes of these relationships were discussed taking into account Cohen's guidelines, in which correlations ranging between .1 and .3 are considered weak, moderate above .3, and strong when equal to or superior than .5, while considering a significance level of .05 (Cohen, Cohen, West, \& Aiken, 2003).

Finally, path analyses were conducted to estimate the presumed relations within the proposed model (Figure 1), specifically the mediating effects of social safeness (SSPS) and body appreciation (BAS-2), in the relationship between early memories of warmth and safeness with family figures (EMWSS) and with peers (EMWSS_peers), and the engagement in disordered eating attitudes and behaviours (EDE-Q). Thus, early memories of warmth and safeness were considered as exogenous variables, social safeness and body appreciation were hypothesized as endogenous mediator variables, and eating psychopathology as an endogenous variable. The Maximum Likelihood method was used to test regression coefficients and to compute fit statistics. Moreover, a series of goodness-of-fit indices were used to examine the adequacy of the overall model (e.g., CMIN/DF; TLI; CFI; RMSEA; $\mathrm{Hu} \&$ Bentler, 1999). The significance of the paths was also examined, by resorting to the Bootstrap resampling method, with 5000 Bootstrap samples, and 95\% bias-corrected confidence intervals around the standardized estimated of total, direct and indirect effects. 


\section{RESULTS}

\section{Preliminary analyses}

The assumption of the normality of the distribution of the variables was confirmed by the analysis of Skewness and Kurtosis (Kline, 1998).

Preliminary analyses indicated that data followed the assumptions of homoscedasticity, normality, linearity, independence of errors and multicollinearity and singularity among the variables (Field, 2004).

\section{Descriptive analyses}

The descriptive statistics referring to the study's variables are presented, for the total sample $(N=490)$, in Table 1 .

Table 1

Means (M), Standard Deviations (SD) and Intercorrelation Scores Between the Study's Measures $(N=490)$

\begin{tabular}{llllllllc}
\hline Measures & $M$ & $S D$ & 1. & 2. & 3. & 4. & 5. & 6. \\
\hline 1.BMI & 22.29 & 3.87 & - & - & - & - & - & - \\
2.EMWSS & 62.58 & 17.64 & $-.14^{* *}$ & - & - & - & - & - \\
3.EMWSS_peers & 34.11 & 11.13 & $-.12^{\star *}$ & $.61^{\star * *}$ & - & - & - & - \\
4.SSPS & 41.59 & 7.90 & $-.10^{*}$ & $-.47^{\star * *}$ & $.55^{\star * *}$ & - & - & - \\
5.BAS-2 & 36.45 & 8.23 & $-.37^{\star * *}$ & $-.34^{\star * *}$ & $.33^{\star * *}$ & $.42^{\star * *}$ & - & - \\
6.EDE-Q & 1.35 & 1.25 & $.44^{\star * *}$ & $-.20^{\star * *}$ & $-.16^{* * *}$ & $-.17^{* * *}$ & $-.67^{\star * *}$ & - \\
\hline
\end{tabular}

Note: ${ }^{*} p<.050,{ }^{* *} p<.010,{ }^{* * *} p<.001 . \mathrm{BMI}=$ Body Mass Index; EMWSS = Early Memories of Warmth and Safeness Scale; EMWSS_peers = Early Memories of Warmth and Safeness ScalePeers version; SSPS = Social Safeness and Pleasure Scale; BAS-2 = Body Appreciation Scale; EDE-Q = Eating Disorder Examination Questionnaire

\section{Descriptive and correlations analyses}

Results demonstrated that age revealed non-significant associations with the variables in study, except with BMI. In turn, BMI presented negative associations, albeit weak, with early memories of warmth and safeness (with family figures EMWSS and with peers - EMWSS_peers) and with social safeness (SPSS). Also, 
results showed that BMI was inversely associated with body appreciation (BAS-2) and positively linked to EDE-Q, both with moderate magnitudes.

EMWSS and EMWSS_peers revealed positive associations with SSPS and with BAS-2 (with moderate and strong magnitudes, respectively), and negative associations with EDE-Q. Moreover, a positive and moderate relationship was found between SSPS and BAS-2. Finally, results showed that SSPS and BAS-2 presented negative associations with EDE-Q, with different magnitudes, weak and strong, respectively (Table 1 ).

In addition, a partial correlation analysis controlling for age was conducted. Results revealed that the direction and magnitude of the correlations of the variables in study remained similar and therefore, age was not included in later analysis.

\section{Path Analysis}

Path Analysis was performed to test whether social safeness (SSPS) and body appreciation (BAS-2) mediate the impact of the recall of early memories of warmth and safeness with family figures and with peers (EMWSS and EMWSS_peers) on disordered eating attitudes and behaviours (EDE-Q), while controlling for the effect of Body Mass Index (BMI).

Firstly, the path model was tested through a saturated model (i.e., zero degrees of freedom), comprising 26 parameters, which explained 51\% of eating psychopathology's variance. Results indicated that three paths were not significant: the direct effect of early memories of warmth and safeness with family figures on EDE-Q $\left(b_{\text {EMwsS }}=-.001 ; S E_{b}=.003 ; Z=-.38 ; p=.707\right)$; the direct effect of early memories of warmth and safeness with peers on EDE-Q ( $b_{\text {EMwss_peers }}=.002 ; S E_{b}=.004 ; Z=$ $.383 ; p=.702$ ), and the direct effect of early memories of warmth and safeness with peers on body appreciation $\left(b_{\text {EMWSS_peers }}=.035 ; S E_{b}=.038 ; Z=.916 ; p=.360\right)$. These paths were progressively eliminated and the model was readjusted.

The final model (Figure 1) presented an excellent fit with a non-significant Chi-Square $\left[\chi^{2}(4)=1.471 ; p=.832\right]$, and an excellent fit to the empirical data, as indicated by the analysis of well-known and recommended goodness of fit indices $(\mathrm{CMIN} / \mathrm{DF}=.368 ; \mathrm{CFI}=1.00 ; \mathrm{TLI}=1.00 ; \mathrm{RMSEA}=.000 ; p=.975, \mathrm{IC}=.00$ / .04; Kline, 2005). This model, in which all path coefficients were statistically significant $(p<.001)$, explained 51\% of EDE-Q's variance. Moreover, the model accounted for $33 \%$ and $30 \%$ of social safeness and body appreciation's variances, respectively. Early memories of warmth and safeness with family figures presented a significant direct effect on social safeness of $.22\left(b_{\text {EMwss }}=.099 ; S E_{b}=.021 ; Z=\right.$ $4.760 ; p<.001)$ and of .15 on body image appreciation $\left(b_{\text {EMwsS }}=.071 ; S E_{b}=.020 ; Z\right.$ 
$=3.557 ; p<.001)$. Early memories of warmth and safeness with peers had a direct effect of .41 on social safeness $\left(b_{\text {EMwss_peers }}=.291 ; S E_{b}=.033 ; Z=8.801 ; p<.001\right)$. In turn, social safeness had a direct effect of .31 on body appreciation $\left(b_{\text {SSPS }}=.326\right.$; $\left.S E_{b}=.045 ; Z=7.302 ; p<.001\right)$ and of -.12 on EDE-Q $\left(b_{\text {SSPS }}=.018 ; S E_{b}=.006 ; Z=\right.$ 3.297; $p<.001)$. It was also verified that body appreciation had a direct effect of -.64 on EDE-Q ( $\left.b_{\text {BAS- } 2}=-.098 ; S E_{b}=.006 ; Z=-17.132 ; p<.001\right)$.

The analysis of indirect effects showed that early memories of warmth and safeness with family figures, as well as with peers, presented indirect effects on EDE-Q through social safeness and body appreciation of .07 (95\% CI = .03 / .14 ) and $.13(95 \% \mathrm{CI}=.08 / .19)$, respectively. Early memories of warmth and safeness with family figures showed an indirect effect of -.12 (95\% CI $=-.18 /-.06)$ on EDE-Q, which was partially carried through the mechanisms of social safeness and body appreciation. Results also demonstrated that social safeness presented an indirect effect of $-.20(95 \% \mathrm{CI}=-.27 /-.13)$ on eating psychopathology, which was partially mediated through body appreciation. Overall, the analysis of this model accounted for $51 \%$ of eating psychopathology's variance, and revealed that social safeness and body appreciation mediate the impact of early memories of warmth and safeness with family figures and with peers on EDE-Q.

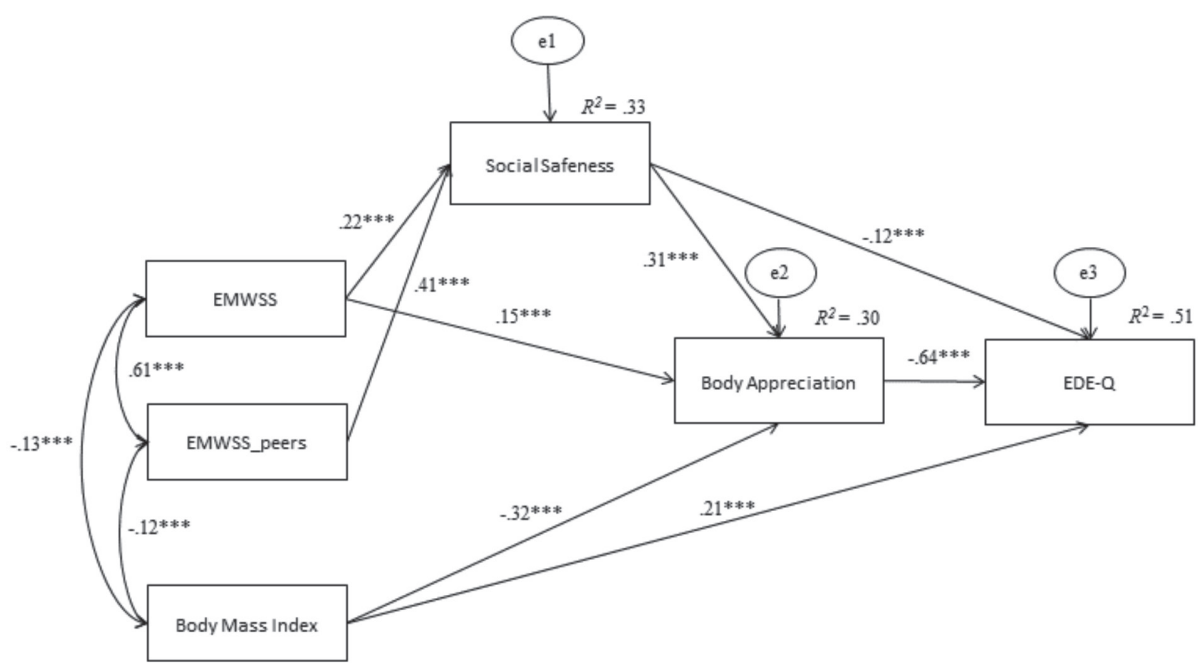

Figure 1. Final path model.

Note. ${ }^{* *} p<.001 ;$ EMWSS = Early Memories of Warmth and Safeness Scale; EMWSS_peers = Early Memories of Warmth and Safeness Scale - Peers version; EDE-Q = Eating Disorder Examination Questionnaire. 


\section{DISCUSSION}

Empirical studies have emphasized the existence of a link between early memories of warmth and safeness and adaptive emotional regulation processes and mental health (Ferreira et al., 2016; Richter et al., 2009; Schore, 1994). Additionally, the impact of the recall of early positive memories (within family figures and peers' relationships) in eating psychopathology was recently documented (e.g., Mendes et al., 2016). Nevertheless, the role of social safeness and body appreciation, as potential mechanisms associated with decreased eating psychopathology symptomatology, remained scarcely explored.

This study intended to clarify the relationship between early memories, social safeness, body appreciation and disordered eating attitudes and behaviours. Specifically, the main aim of the current study was to test an integrative model that explored the effect of early memories of warmth and safeness on eating psychopathology's severity and the mediating roles of social safeness and body appreciation in this association, while controlling the effect of BMI.

In accordance with the proposed hypotheses and with prior research, the results of correlation analyses showed that early memories of warmth and safeness (both with family figures and with peers) were significantly associated with adaptive emotions and processes, and with lower eating psychopathology's severity (e.g., Ferreira et al., 2016; Mendes et al., 2016; Richter et al., 2009). Particularly, the current study extends current knowledge by demonstrating that the recall of positive emotional experiences is significantly associated with individuals' sense of safeness and connectedness to others, and with a positive attitude towards one's body, regardless of its characteristics. These findings are in line with theoretical and empirical evidence suggesting that the evocation of supportive memories plays a crucial role on the promotion of social and psychological adjustment (Gilbert \& Irons, 2009; Gilbert \& Procter, 2006). Nonetheless, this is the first study documenting a positive link between these positive mechanisms (evocation of being nurtured and cared for within early relationships, current feelings of warmth, acceptance and connectedness, a respecting and caring attitude towards body image), and its inverse relation with the severity of eating psychopathology's symptoms.

Path analysis' findings revealed that the examined model showed an excellent fit to the empirical data, accounting for $51 \%$ of the variance of disordered eating attitudes and behaviours. Furthermore, results revealed that $33 \%$ of social safeness's variance was explained by early memories of warmth and safeness, both with family figures and with peers. Additionally, this model suggested that $30 \%$ of the variance of body appreciation was directly explained by the evocation of early supportive memories with family figures, and by the indirect effect of family and peer-related 
early positive memories, through social safeness. Also, results revealed that early positive memories explained lower levels of disordered eating via higher levels of social safeness and body appreciation, while controlling for the effect of BMI.

This model proposes that women's ability to recall early positive emotional experiences predicted lower levels of disordered eating behaviours, even when controlling the effect of BMI. However, these results seem to suggest that the relationship between early warmth and safeness memories and eating psychopathology's severity is complex and influenced by different mechanisms. In fact, path analysis' results indicated that the effect of the evocation of positive affiliative memories on disordered eating is mediated by the tendency to perceive the social world as safe, warm, and soothing and by a positive and caring relationship with one's body. Indeed, this study suggests that affiliative memories with family figures and peers promote feelings of warmth, acceptance and connectedness with others. In turn, these positive memories and current feelings of social safeness seem to be linked to a more adaptive and positive relation with one's body, regardless of its characteristics. Also, feelings of acceptance and connectedness with others and the ability to relate with one's body in an accepting and caring manner seem to be targeted in psychological interventions to decrease eating psychopathology. These results can be understood in light of the evolutionary model (e.g., Baumeister \& Leary, 1995; Gilbert, 2000, 2010), which emphasizes the central role of social acceptance and approval in well-being and mental health. Eating disorders' symptoms, specifically weight and body image control, may arise from the perception of being in an unsafe position in relation to one's social group (e.g., Pinto-Gouveia et al., 2014) and as a strategy to compete for others' acceptance and positive attention (Ferreira et al., 2014). In this line, our results corroborate prior research by showing that nurturing a positive and caring relationship with one's body is negatively associated with eating psychopathology (Tylka \& Wood-Barcalow, 2015), and is suggested as an important mediator mechanism in the explanation of disordered eating behaviours.

To sum up, it is possible to hypothesise that feelings of warmth and safeness in social relationships may explain the need to control or conceal body image in order to enhance social acceptance. Furthermore, early emotional experiences and current feelings of connectedness may allow women to recognize that some negative experiences related to body image (e.g., perception of flaws in appearance) are shared among women, which enhances a sense of respect and acceptance towards body image, regardless of undesired characteristics. The promotion of a holistic and positive relationship with one's own body may, therefore, play a powerful role in the prevention of disordered eating attitudes and behaviours.

Nevertheless, these findings cannot be understood without considering some limitations. One important limitation is that the cross-sectional design precludes 
causal conclusions to be drawn. Future research should test the relationships between the study's variables in longitudinal or experimental design studies. Also, the use of a sample exclusively composed of female participants represents an important limitation. Even though eating psychopathology is more prevalent in women, men also experience weight and body image-related difficulties and this study sample does not allow the generalization of the obtained results. Thus, upcoming studies should investigate this model in male samples and explore gender differences. Moreover, future research should also investigate these associations in larger samples and, in particular, the plausibility of this mediational model in clinical samples. Also, although the main aim of the current study was to specifically address the mediating role of social safeness and body appreciation, the complex nature of eating psychopathology presupposes the existence of other relevant variables in the link between memories of warmth and safeness and disordered eating. Future studies should then expand on this model by testing different meditating mechanisms. Finally, our data may be constrained by limitations related to the use of self-report measures, specifically retrospective reports; nevertheless some studies have shown that memories of early parenting are relatively reliable and stable over time, even in the face of considerable changes in mood and emotional states (e.g., anxiety, depression, and hostility; Brewin, Andrews, \& Gotlib, 1993; Cunha, Xavier, Martinho, \& Matos, 2014; Gerlsma, Kramer, Scholing, \& Emmelkamp, 1994). Future studies should further validate the current findings by using other assessment methodologies, such as face-to-face interviews or observational instruments.

In conclusion, our results seem to support that women who evoke more early warmth and safeness experiences tend to perceive their current interpersonal interactions as supportive and safe, and present a positive, accepting and respecting attitude towards their body, regardless of its appearance. Moreover, this study offers new insights on how feelings of acceptance and connectedness with others and a positive and kind relationship towards one's own body can be important mediating mechanisms of the link between early affiliative memories and lower tendency to engage in disorder eating, in women. In this line, our results seem to reveal that the impact of these early emotional memories on eating psychopathology may be highly dependent to the existence of feelings of acceptance and connectedness in social interactions and the ability to have compassionate attitudes towards one's own body. Our findings provide an important contribution to prevention and therapeutic interventions targeting women with body and eating difficulties. This study suggests that specific work promoting affiliative processes, and particularly a more positive relation with body image, may be helpful to attenuate the impact of the lack of early memories of warmth and safeness within family figures and peers. 


\section{REFERENCES}

Arbuckle, J. (2008). Analysis of Moment Structures (AMOS) 17.0.0. Crawfordville, FL: AMOS Development Corporation.

Avalos, L., Tylka, T., \& Wood-Barcalow, N. (2005). The Body Appreciation Scale: Development and psychometric evaluation. Body Image, 2(3), 285-297. doi:10.1016/j.bodyim.2005.06.002

Baldwin, M., \& Dandeneau, S. (2005). Understanding and modifying the relational schemas underlying insecurity. In M. Baldwin (Ed.), Interpersonal cognition (pp. 33-61). New York: Guilford Press.

Baumeister, R., \& Leary, M. (1995). The need to belong: Desire for interpersonal attachments as a fundamental human motivation. Psychological Bulletin, 117(3), 497-529. doi:10.1037/0033-2909.117.3.497

Bowlby, J. (1969). Attachment and loss. Vol. 1: Attachment. London: Hogarth Press.

Bowlby, J. (1973). Attachment and loss. Vol. 2: Separation, anxiety and anger. London: Hogarth Press.

Brewin, C., Andrews, B., \& Gotlib, I. (1993). Psychopathology and early experience: A reappraisal of retrospective reports. Psychological Bulletin, 113(1), 82-98. doi: 10.1037/0033-2909.113.1.82

Cohen, J., Cohen, P., West, S., \& Aiken, L. (2003). Applied multiple regression/correlation analysis for the behavioural sciences ( $3^{\text {th }}$ ed.). New Jersey: Lawrence Erlbaum Associates.

Collins, A., Maccoby, E., Steinberg, L., Heatherington, M., \& Bornstein, M. (2000). Contemporary research on parenting: The case for nature and nurture. American Psychologist, 55(2), 218-232. doi: 10.1037/0003-066X.55.2.218

Cunha, M., Xavier, A., Martinho, M., \& Matos, M. (2014). Measuring positive emotional memories in adolescents: Psychometric properties and confirmatory factor analysis of the early memories of warmth and safeness scale. International Journal of Psychology and Psychological Therapy, 14(2), 245-259. Retrieved from: http://www.ijpsy.com/volumen14/num2/386/measuring-positive-emotional-memories-in-EN.pdf

DeHart, T., Peham, B., \& Tennen, H. (2006). What lies beneath: Parenting style and implicit self-esteem. Journal of Experimental Social Psychology, 42(1), 1-17. doi: 10.1016/j.jesp.2004.12.005

Depue, R., \& Morrone-Strupinsky, J. (2005). A neurobehavioral model of affiliative bonding: Implications for conceptualizing a human trait of affiliation. Behavioral and Brain Sciences, 28(3), 313-395. doi: 10.1017/S0140525X05000063

Fairburn, C., \& Beglin, S. (1994). Assessment of eating disorders: Interview of self-report questionnaire? International Journal of Eating Disorders, 16(4), 363-370. doi: 10.1002/1098-108X(199412)

Ferreira, C., Cunha, M., Marta-Simões, J., Duarte, C., Matos, M., \& Pinto-Gouveia, J. (2016). Development of a measure for the assessment of peer-related positive emotional memories. Manuscript submitted for publication.

Ferreira, C., Matos, M., Duarte, C., \& Pinto-Gouveia, J. (2014). Shame memories and eating psychopathology: The buffering effect of self-compassion. European Eating Disorders Review, 22(6), 487-494. doi: 10.1002/erv.2322

Ferreira, C., Pinto-Gouveia, J., \& Duarte, C. (2013) Physical appearance as a measure of social ranking: The role of a new scale to understand the relationship between weight and dieting. Clinical Psychology and Psychotherapy, 20(1), 55-66. doi: 10.1002/cpp.769

Field, A. (2004). Discovering statistics using SPSS (3 ${ }^{\text {th }}$ ed.). London: Sage Publications.

Gerhardt, S. (2004). Why love matters: How affection shapes a baby's brain. London: Bruner-Routledge.

Gerlsma, C, Kramer, J., Scholing, A., \& Emmelkamp, P. (1994). The influence of mood on memories of parental rearing practices. British Journal of Clinical Psychology, 33(2), 159-172. doi:10.1111/j.2044-8260.1994.tb01107.x 
Gilbert, P. (1989). Human Nature and Suffering. Hove: Lawrence Erlbaum Associates.

Gilbert, P. (2000). Social mentalities: Internal 'social' conflicts and the role of inner warmth and compassion in cognitive therapy. In P. Gilbert \& K. Bailey (Eds.), Genes on the Couch: Explorations in evolutionary psychotherapy (pp. 118-150). Hove: Psychology Press.

Gilbert, P. (2005). Social mentalities: A biopsychosocial and evolutionary reflection on social relationships. In M. Baldwin (Ed.), Interpersonal cognition (pp. 299-335). New York: Guilford.

Gilbert, P. (2009). The compassionate mind: A new approach to life's challenges. London: Constable Robinson.

Gilbert, P. (2010). Compassion focused therapy: Distinctive features. London: Routledge.

Gilbert, P., Cheung, M., Grandfield, T., Campey, F., \& Irons, C. (2003). Recall of threat and submissiveness in childhood: Development of a new scale and its relationship with depression, social comparison and shame. Clinical Psychology and Psychotherapy, 10(2), 108-115. doi:10.1002/cpp.359

Gilbert, P., \& Irons, C. (2009). Shame, self-criticism, and self-compassion in adolescence. In N. Allen \& L. Sheeber (Eds.), Adolescent emotional development and the emergence of depressive disorders (pp. 195-214). Cambridge: Cambridge University Press.

Gilbert, P., \& Perris, C. (2000). Early experiences and subsequent psychosocial adaptation: An introduction. Clinical Psychology and Psychotherapy, 7(4), 243-245. doi:10.1002/1099-0879(200010)7:4<243::AID-CPP254>3.0.CO;2-H

Gilbert, P. \& Procter, S. (2006). Compassionate mind training for people with high shame and self-Criticism: Overview and pilot study of a group therapy approach. Clinical Psychology and Psychotherapy, 13(6), 353-379. doi: 10.1002/cpp.507

Gilbert, P., McEwan, K., Mitra, R., Franks, L., Richter, A., \& Rockliff, H. (2008). Feeling safe and content: A specific affect regulation system? Relationship to depression, anxiety, stress, and self-criticism. The Journal of Positive Psychology, 3(3), 182-191. doi: 10.1080/17439760801999461

Gilbert, P., McEwan, K., Mitra, R., Richter, A., Franks, L., Mills, A., \& Gale, C. (2009). An exploration of different types of positive affect in students and patients with bipolar disorder. Clinical Neuropsychiatry, 6(4), 135-143.

Goss, K., \& Allan, S. (2009). Shame, pride and eating disorders. Clinical Psychology \& Psychotherapy, 16(4), 303-316. doi:10.1002/cpp. 627

Goss, K., \& Gilbert, P. (2002). Eating disorders, shame and pride: A cognitive-behavioural functional analysis. In P. Gilbert \& J. Miles (Eds.), Body shame: Conceptualization, research \& treatment (pp. 219-255). Hove, UK: Brunner-Routledge.

Homan, K., \& Tylka, T. (2015). Self-compassion moderates body comparison and appearance self-worth's inverse relationships with body appreciation. Body Image, 15, 1-7. doi: 10.1016/j. bodyim.2015.04.007

Hu, L., \& Bentler, P. (1999) Cutoff criteria for fit indexes in covariance structure analysis: Conventional criteria versus new alternatives. Structural Equation Modelling: A Multidisciplinary Journal, 6(1), 1-55. doi: 10.1080/10705519909540118

Irons, C., Gilbert, P., Baldwin, M., Baccus, J., \& Palmer, M. (2006). Parental recall, attachment relating and self-attacking/self-reassurance: Their relationship with depression. British Journal of Clinical Psychology, 45(3), 297-308. doi:10.1348/014466505X68230

Kelly, A., Zuroff, D., Leybman, M., \& Gilbert, P. (2012). Social safeness, received social support, and maladjustment: Testing a tripartite model of affect regulation. Cognitive Therapy and Research, 36(6), 815-826. doi: 10.1007/s10608-011-9432-5 
Kline, R. (1998). Principles and practice of structural equation modelling ( $2^{\text {nd }}$ ed.) New York: The Guildford Press.

Machado, P., Martins, C., Vaz, A., Conceição, E., Bastos, A., \& Gonçalves, S. (2014). Eating Disorder Examination Questionnaire: Psychometric properties and norms for the Portuguese population. European Eating Disorders Review, 22(6), 448-453. doi: 10.1002/erv.2318

Marta-Simões, J., Mendes, A. L., Oliveira, S., Trindade, I. A., \& Ferreira, C. (2016, May). Validation of the Body Appreciation Scale-2 for the Portuguese population. Paper presented at the $3^{\text {rd }}$ IPLeiria International Health Congress, Leiria, Portugal.

Matos, M., \& Pinto-Gouveia, J. (2010). Shame as a traumatic memory. Clinical Psychology and Psychotherapy, 17(4), 299-312. doi: 10.1002/cpp.659

Matos, M., Pinto-Gouveia, J., \& Duarte, C. (2014). Psychometric properties of the Portuguese version of the Early Memories of Warmth and Safeness Scale. Manuscript Submitted for Publication.

Mendes, L., Marta-Simões, J., \& Ferreira, C. (2016). How can the recall of early affiliative memories with peers influence on disordered eating behaviours? Eating and Weight Disorders. Advance online publication. doi: 10.1007/s40519-016-0267-7

Panksepp, J. (2010). Affective neuroscience of the emotional BrainMind: Evolutionary perspectives and implications for understanding depression. Dialogues in Clinical Neuroscience, 12(4), 533-545.

Pinto-Gouveia, J., Ferreira, C., \& Duarte, C. (2014). Thinness in the pursuit for social safeness: An integrative model of social rank mentality to explain eating psychopathology. Clinical Psychology and Psychotherapy, 21(2), 154-165. doi: 10.1002/cpp.1820

Pinto-Gouveia, J., Matos, M., \& Dinis, A. (2008). Portuguese version of the social safeness and pleasure scale. Unpublished manuscript.

Poínhos, R., Franchini, B., Afonso, C., Correia, F., Teixeira, V. H., Moreira, P., ... Almeida, M. D. V. (2009). Alimentação e estilos de vida da população Portuguesa: Metodologia e resultados preliminares. Alimentação Humana, 15(3), 43-60. Retrieved from: http://www.alimentacaosaudavel.dgs.pt/ activeapp/wp-content/files_mf/1445339604alimenta\%C3\%A7\%C3\%A3oeestilosdevidadapopula \%C3\%A7\%C3\%A3oportuguesa.pdf

Richter, A., Gilbert, P., \& McEwan, K. (2009). Development of an early memories of warmth and safeness scale and its relationship to psychopathology. Psychology and Psychotherapy: Theory, Research and Practice, 82(2), 171-184. doi: 10.1348/147608308X395213

Schore, A. (1994). Affect regulation and the origin of the self: The neurobiology of emotional development. Hillsdale: Lawrence Erlbaum.

Tylka, T., \& Wood-Barcalow, N. (2015). The Body Appreciation Scale-2: Item refinement and psychometric evaluation. Body Image, 12, 53-67. doi:10.1016/j.bodyim.2014.09.006

Vartanian, L., Smyth, J., Zawadzki, M., Heron, K., \& Coleman, S. (2014). Early adversity, personal resources, body dissatisfaction, and disordered eating. International Journal of Eating Disorders, 47(6), 620-629. doi:10.1002/eat.22313

Xavier, A., Cunha, M., \& Pinto-Gouveia, J. (2015). Deliberate self-harm in adolescence: The impact of childhood experiences, negative affect and fears of compassion, Revista de Psicopatología Y Psicología Clínica, 20(1), 41-49. doi: 10.5944/rppc.vol.1.num.1.2015.14407 